\title{
Intersphincteric Resection for Low Rectal Cancer: A Review of Anatomy and Surgical Techniques, Oncologic and Functional Outcomes and the Role of Robotics
}

\author{
Aşağı Yerleşimli Rektal Kanser İçin İntersfinkterik Rezeksiyon: Anatomi, \\ Cerrahi Teknikler, Onkolojik ve Fonksiyonel Sonuçlar ve Robotik \\ Cerrahinin Rolü Üzerine Derleme
}

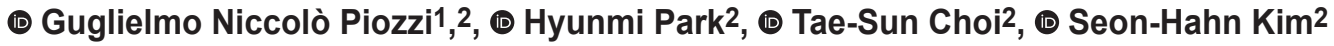 \\ ${ }^{1}$ Colorectal Surgery Unit, Department of Surgery, Fondazione IRCCS Istituto Nazionale dei Tumori, Milano, Italy \\ ${ }^{2}$ Korea University Anam Hospital, Korea University College of Medicine, Division of Colorectal Surgery, Department of Surgery, Seoul, Korea
}

\section{|IIII\|II| ABSTRACT}

Intersphincteric resection (ISR) for low rectal cancer is a relatively novel anal-sparing technique that requires a thorough knowledge of the anatomy of the deep pelvic space and advanced surgical skills. The development of laparoscopic intersphincteric resection, through magnification of the surgical field, has renewed the interest in the anatomical description of the anal canal and deep pelvis, which has been historically fraught with inconsistencies. Introduction of the robotic platform has made the deep pelvis technically accessible to a greater number of colorectal surgeons. The literature describes ISR as an oncologically safe technique with good functional outcomes; however, there is often confusion regarding its definition, indications and technical aspects of this challenging procedure. This review aims to evaluate the current state of robotic ISR through the discussion of novel detailed anatomical descriptions, surgical techniques and indications, together with oncological and functional results.

Keywords: Anatomy, intersphincteric resection, rectal cancer

\section{HIIIIIII ÖZ}

Aşağı yerleşimli rektal kanser için intersfinkterik rezeksiyon (ISR), derin pelvik boşluğun anatomisi ve ileri cerrahi beceriler hakkında kapsamlı bilgi gerektiren nispeten yeni bir anüs koruyucu tekniktir. Cerrahi alanın büyütülmesi yoluyla laparoskopik intersfinkterik rezeksiyonun gelişimi, tarihsel olarak tutarsızlıklar ile dolu olan anal kanalın ve derin pelvisin anatomik tanımına olan ilgiyi yeniledi. Robotik platformun tanıtımı, derin pelvisi teknik olarak çok sayıda kolorektal cerrah için erişilebilir hale getirdi. Literatür, İSR'yi iyi fonksiyonel sonuçları olan onkolojik olarak güvenli bir teknik olarak tanımlamaktadır ancak, bu zorlayıcı prosedürün tanımı, endikasyonları ve teknik yönleri ile ilgili genellikle kafa karışıklığı vardır. Bu derleme, yeni detaylı anatomik tanımlar, cerrahi teknikler ve endikasyonların yanı sıra onkolojik ve fonksiyonel sonuçların tartışılmasıyla robotik İSR'nin mevcut durumunu değerlendirmeyi amaçlamaktadır.

Anahtar Kelimeler: Anatomi, intersfinkterik rezeksiyon, rektal kanser

\section{Introduction}

Sir Ernest Miles introduced the abdominoperineal resection (APR) with a permanent colostomy in 1908 for the treatment of low rectal cancers [below $5 \mathrm{~cm}$ from the anal verge
(AV)], which has been the standard of care in most surgical practices ever since. ${ }^{1}$ In 1994, Schiessel et al. ${ }^{2}$ introduced the intersphincteric resection (ISR), followed by hand-sewn coloanal anastomosis, as a novel anal-sparing technique.

Address for Correspondence/Yazışma Adresi: Seon-Hahn Kim MD,

Korea University Anam Hospital, Korea University College of Medicine, Division of Colorectal Surgery, Department of Surgery, Seoul, Korea

E-mail: drkimsh@korea.ac.kr ORCID ID: orcid.org/0000-0002-4526-5147

Received/Geliş Tarihi: 17.03.2020 Accepted/Kabul Tarihi: 19.03.2020

${ }^{\odot}$ Copyright 2020 by Turkish Society of Colon and Rectal Surgery

Turkish Journal of Colorectal Disease published by Galenos Publishing House. 
The introduction of ISR has revived interest in a deeper understanding of anorectal anatomy in order to optimize dissection through the intersphincteric plane (ISP). Laparoscopic ISR was introduced to improve post-operative short-term outcomes and recovery whilst providing as safe an oncological outcome as open surgery. ${ }^{3}$ However, laparoscopic ISR is not a widespread technique due to its technically challenging nature, with only few specialized centers being able to offer such anal sparing resection. ${ }^{4,5}$

Complex pelvic surgery benefits from the technical advantages offered by the robotic platform ${ }^{5}$, which results in similar oncological outcomes for ISR as with other conventional surgical approaches but with improved postoperative pelvic function. ${ }^{6,7}$

This paper reviews the current state of robotic ISR through a discussion of novel, detailed anatomical descriptions, surgical indications and oncological and functional results.

\section{Surgical Anatomy of the Intersphincteric Plane}

The low pelvic anatomy contains, in close proximity, the genitourinary complex, the rectum/anal canal and the pelvic nerves and vessels within a funnel shaped rigid muscular-tendinous structure, making it a very challenging surgical field for novice surgeons. ${ }^{8}$ The introduction of ISR has challenged modern anatomical studies through the combined use of immunostaining, magnetic resonance imaging (MRI) and endoscopic ultrasound (EUS) on both cadaveric and live patients in order to better outline the enigmatic virtual space that is the ISP, which has often been a source of long-lasting anatomic inconsistencies.

The pelvis can be divided schematically into four quadrants (anterior, posterior and two laterals) with specific anatomic landmarks that should be identified for a correct ISP dissection.

\section{Posterior Aspect of the Distal Rectum/Anal Canal}

The mucous membrane of the distal rectum/anal canal is surrounded by the muscularis propria, composed of a circular (interior) and longitudinal (exterior) layer of smooth muscle cells. In the anal canal, the circular muscle forms the internal anal sphincter (IAS). The longitudinal muscle (LM) of the anal canal is composed of an inner sheet of dense smooth muscle cells organized in bundles surrounded both internally and externally by sparsely scattered smooth muscle fibers. ${ }^{9}$ Cranially, the cells of the LM are directly attached to the skeletal muscle fibers of the levator ani muscle (LAM) (Figures la and 8). ${ }^{9}$ Caudally, the LM penetrates the inferior (i.e. subcutaneous) part of the external anal sphincter (EAS), splitting into fibers running antero-inferiorly and terminating subcutaneously (Parks' ligament $)^{10}$ and others running posteriorly and cranially forming a ligamentous loop composed of collagenous and elastic fibers terminating on the dorsal side of the coccyx. This ligamentous loop was defined by Muro et al. ${ }^{11}$ as the anococcygeal ligament (ACL) following Toldt's description in 1903 in an attempt to standardize the international anatomic terms. ${ }^{12}$ The EAS is located circumferentially outside of the LM and anteriorly to the ACL and has been described to be composed of three (deep, superficial and subcutaneous) ${ }^{13}$ or one continuous sheet. ${ }^{14}$ There is a space in the sentence EAS is a skeletal muscle which continues cranially into the LAM, which is composed of three portions (the puborectalis, pubococcygeus and anococcygeus) but is macroscopically a continuous muscular structure.

The LAM adheres tightly to the ventral surface of the coccyx through a dense connective tissue called Raphe of the iliococcygeus and pubococcygeus muscle. ${ }^{11} \mathrm{~A}$ thick tissue located above the LAM, composed of smooth muscle cells, connects the posterior aspect of the LM to the ventral surface of the coccyx. ${ }^{11,15}$ This was named by Muro et al. ${ }^{11}$ as the "hiatal ligament" (HL) according to a previous description from Shafik ${ }^{16}$; however, it is traditionally classified by colorectal surgeons as the "anococcygeal ligament" (Figure 1b). The ISP is located between the posterior loose portion of the LM and the EAS, and it is accessible transabdominally through the dissection of the HL close to the viscera (Figures 2 and 3). Therefore, the surgical landmark for a correct posterior dissection is the initial exposure and dissection of the HL.

\section{Anterior Aspect of the Distal Rectum/Anal Canal}

The anterior region of the anal canal has many similarities between the two genders, and correct anatomical knowledge of it is paramount for correct dissection of the ISP. Nakajima et al. ${ }^{17}$ and Muro et al. ${ }^{18}$ have investigated the anterior aspect
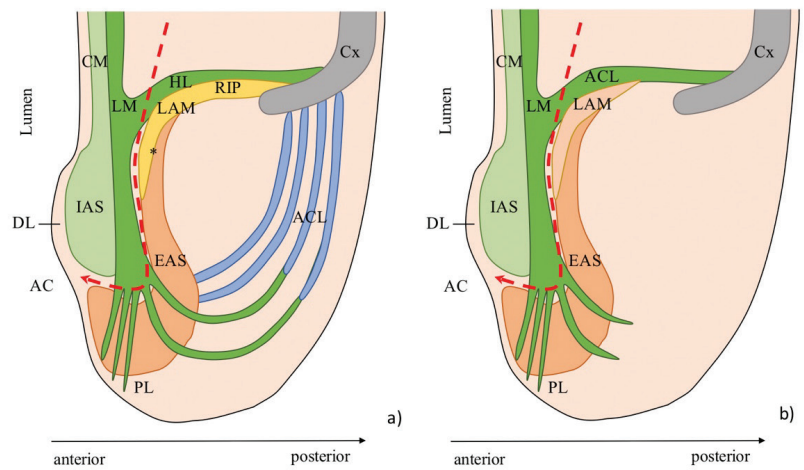

Figure 1. Posterior aspect of the rectal/anal canal. The figures represent the different view between anatomists (a) and colorectal surgeon's clinical experience (b). AC: Anal canal, ACL: Anococcygeal ligament, Cx: Coccyx, CM: Circular muscle of the anal canal, EAS: External anal sphincter, HL: Hiatal ligament, IAS: Internal anal sphincter, LM: Longitudinal muscle of the anal canal, PL: Park's ligament, RIP: Raphe of ileococcygeus and pubococcygeus muscle; *: Overlap between the LAM and EAS, red line: Intersphincteric plane for total ISR. The anatomic model has been designed according to the descriptions of Muro et al. ${ }^{11}$ 
through cadaveric dissections and anorectal EUS. From the lumen towards the anterior direction lies the mucous membrane of the distal rectum/anal canal, the IAS, the LM and finally the EAS. The difference between genders arises on the distribution of the fibers of the LM. In males the LM fibers of the distal rectum run downwards tridirectionally (Figure 4): 1) Posterior to the EAS, therefore covering the anterior aspect of the IAS; 2) Anterior to the EAS, forming the anterior bundle of the LM (AB), which is sandwiched between the bulbospongiosus muscle and the EAS and terminates in loose connective tissue and 3) Anteriorly into the rectourethralis muscle (RU). ${ }^{17}$ In females, the LM fibers coming from the rectum run bidirectionally (Figure 5): 1) The medial fibers of the LM run downwards and, together with the IAS, they converge anteriorly merging into the posterior vaginal smooth muscle layer (MV), the vaginal vestibule and the perineum covering the anterior surface of the EAS and forming an area of muscular intermingling. 2) The lateral fibers of the LM run downwards and medially between the EAS and IAS. ${ }^{18}$ Several studies describe the presence of the perineal body (PB) as a fibromuscular tissue in the region between the rectum and the urogenital

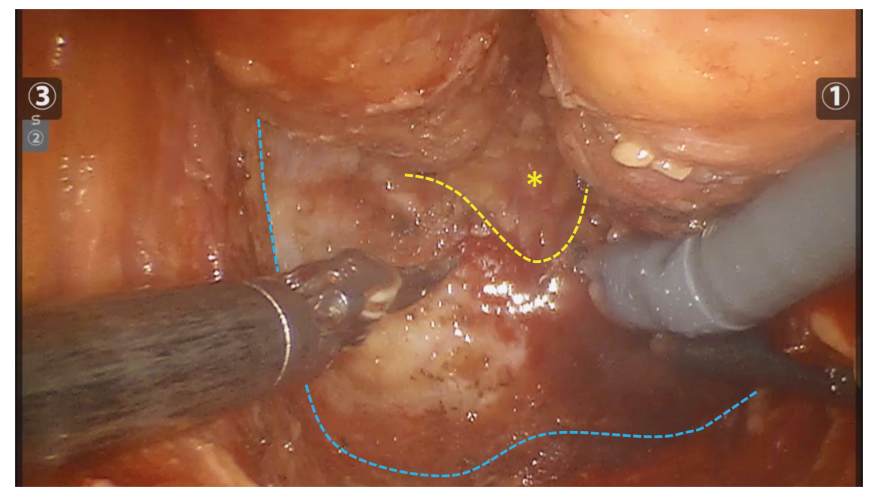

Figure 2. Intra-operative view of the posterior aspect of the rectum after complete exposure of the pelvic floor. Blue dotted line: anterior margin of the sacrum. Yellow intermitted line: margins of the HL before dissection. Star: HL

HL: Hiatal ligament

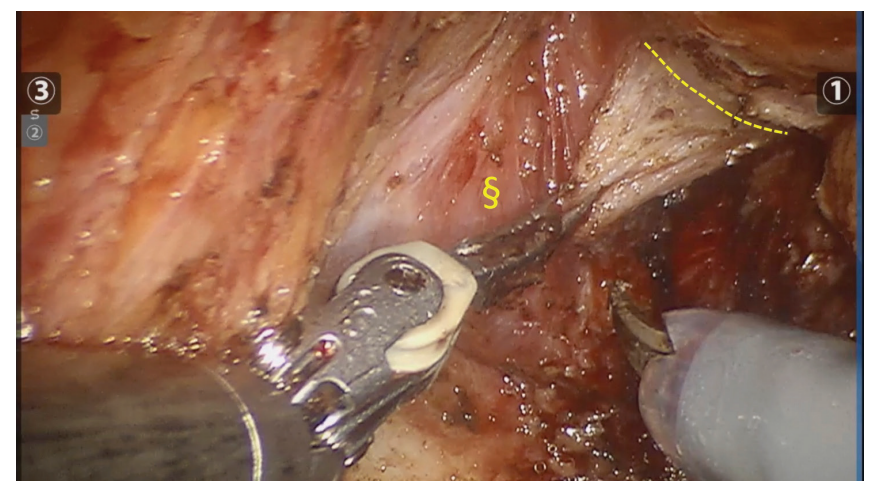

Figure 3. Intra-operative view of the intersphincteric plane after dissection of the HL. Dotted yellow line: ISP. Symbol §: LAM

HL: Hiatal ligament, ISP: Intersphincteric plane, LAM: Levator ani muscle structures with a mechanical stabilizing effect. ${ }^{19,20,21}$ The PB could also be described as the above-mentioned anatomical complex of muscular intermingling between the LM, IAS and EAS.

On the anterior aspect, there is no anatomical clear ISP, as described for the posterior aspect, so the dissection should follow the LM dividing through the fibers running anteriorly both in males (to the RU) and females (area of muscular intermingling between the anal and vaginal muscles) in order to access the correct plane for ISP dissection (Figures 6 and 7). Therefore, the surgical landmark for a correct anterior dissection in males is the posterior aspect of the $\mathrm{RU}$,

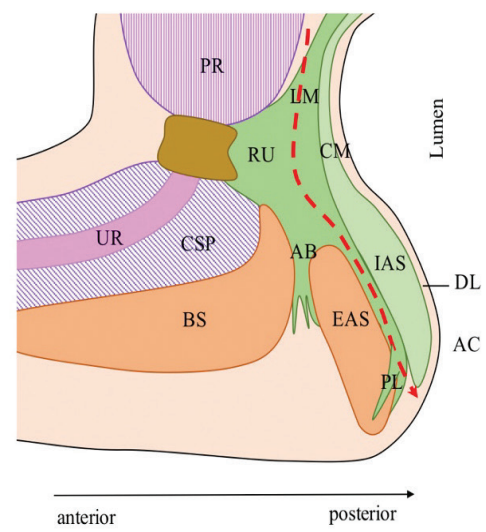

Figure 4. Scheme of the male anatomy of the anterior aspect of the recta/anal canal. AB: anterior bundle of the LM; AC: Anal canal, BS: Bulbospongiosus muscle, CM: Circular muscle of the anal canal, CSP: Corpus spongiosum of the penis; DL: Dentate line, EAS: External anal sphincter; IAS: İnternal anal sphincter; LM: Longitudinal muscle of the anal canal, PL: Park's ligament, PR: prostate, R: Rectum, RU: Rectourethralis muscle, UR: Urethra, red line: dissection plane for accessing the intersphincteric plane for total ISR. The anatomic model has been designed according to the descriptions of Nakajima et al. ${ }^{17}$

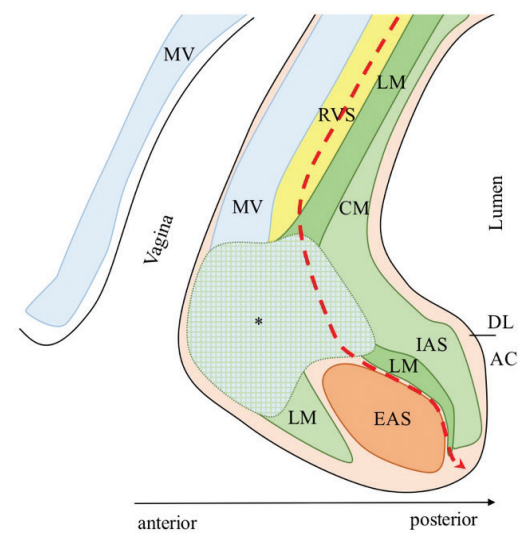

Figure 5. Scheme of the female anatomy of the anterior aspect of the recta/anal canal. AC: anal canal, CM: Circular muscle of the anal canal, DL: Dentate line, EAS: External anal sphincter, IAS: İnternal anal sphincter, LM: Longitudinal muscle of the anal canal, MV: Muscle layer of the vagina, RVS: Rectovaginal septum, *: Area of intermingling between muscle fibers of the LM, the MV and the IAS; red line: Dissection plane for accessing the intersphincteric plane for total ISR. The anatomic model has been designed according to the descriptions of Muro et al. ${ }^{18}$ 
whilst in females it is the area of muscular intermingling. The anatomist Muro et al. ${ }^{18}$, after describing the absence of a surgical plane on the midline, recommends to the surgeon that, due to the presence of a "relatively sparse space in the region anterolateral to the rectum", it could be preferable to approach it laterally before directly detaching the anorectal canal from the vagina in order to reduce the possibility of injury.

\section{Lateral Aspect of the Distal Rectum/Anal Canal}

The lateral aspect of the anal canal was described in detail by Tsukada et al. ${ }^{15}$ through cadaveric and surgical specimens. The structures are similar to the previously discussed posterior anatomy; however, the following three differences should be considered (Figure 8). Firstly, the smooth muscle

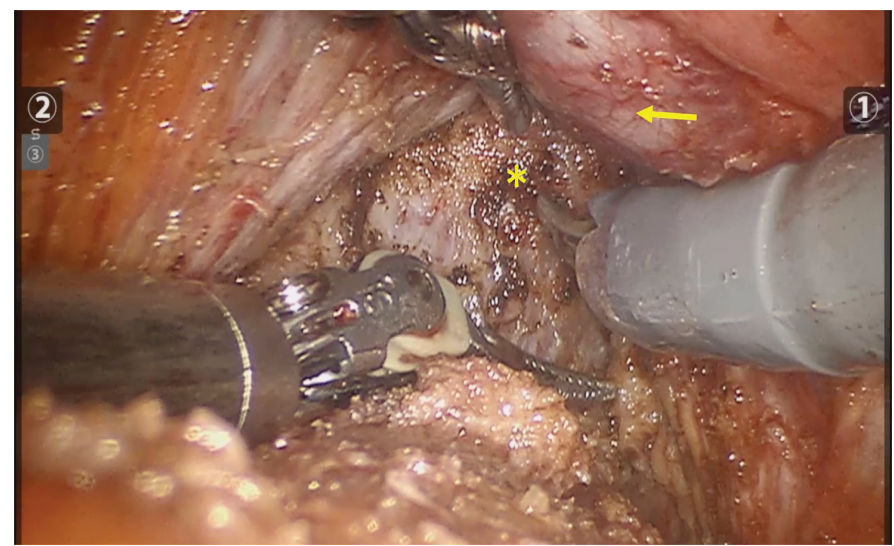

Figure 6. Intra-operative view of the anterior portion in a male patient. *: View of the LM fibers connecting to the posterior aspect of the RU in the male; arrow: prostate

LM: Longitudinal muscle, RU: Rectourethralis muscle

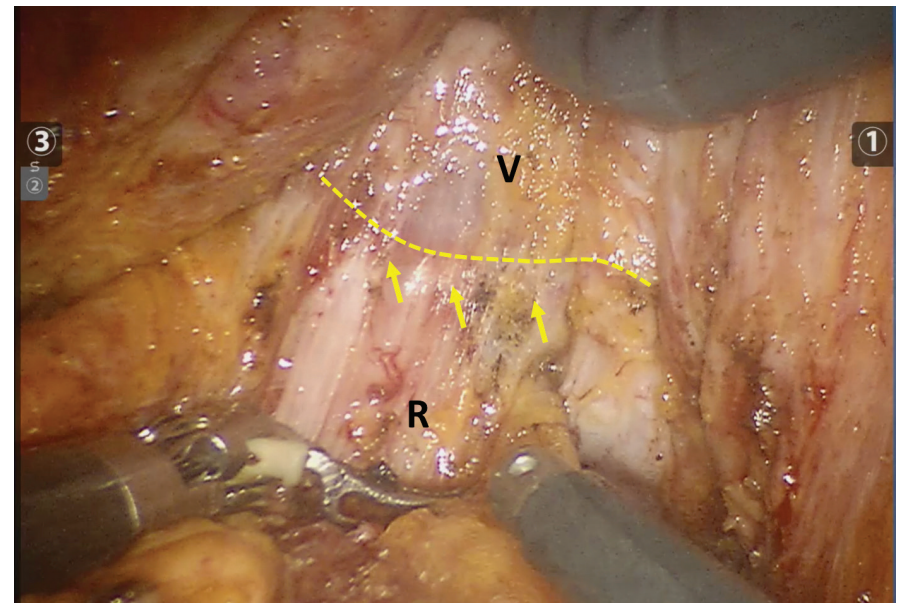

Figure 7. Intra-operative view of the anterior portion in a female patient. V: Posterior wall of the vagina, R: Anterior wall of the rectum/anal canal, dotted line: Plane between the posterior muscle layer of the vagina and the longitudinal muscle of the rectum/anal canal; arrows: Dense tissue corresponding to the intermingling area between the LM, the IAS and the MV described by Muro et al. ${ }^{18}$

LM: Longitudinal muscle, IAS: Internal anal sphincter, MV: Muscle layer of the vagina layer covering the LAM forming the HL is very thin in this portion. Secondly, the length of the attachment between the LM and the LAM decreases significantly in an anteriorto-posterior direction, with the anterolateral having the greater extension. Thirdly, the overlap between the LAM and the EAS increases as it moves posteriorly. ${ }^{15}$ The surgical landmark for a correct lateral dissection is the plane found between the medial edge of the LAM (identified through muscle contraction with electrocautery) and the rectum (Figure 9).

\section{Surgical Considerations for ISP Dissection}

The correct identification of the ISP is challenging because of the above-mentioned anatomical complexities surrounding the anal canal. The dissection plane should be identified carefully during both abdominal and perianal phases. The

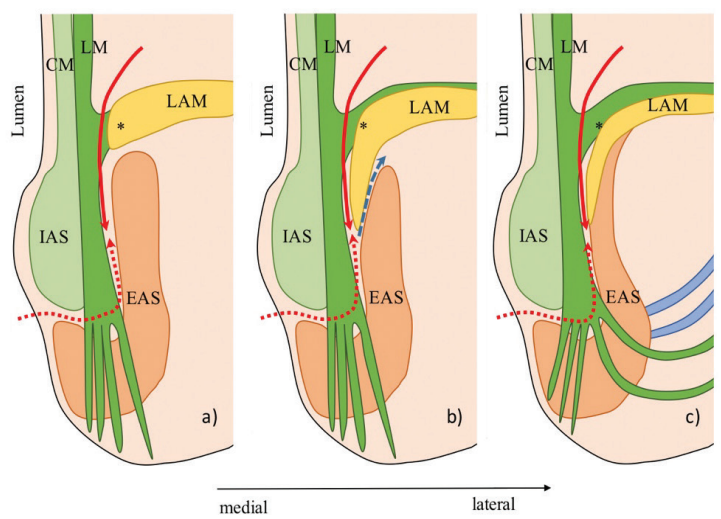

Figure 8. Three views of the anatomy of the rectum/anal canal. Anterolateral (a), lateral (b) and posterior (c) view of the anatomy of the anal canal. CM: Circular muscle of the anal canal, EAS: External anal sphincter, IAS: Internal anal sphincter, LM: Longitudinal muscle of the anal canal, *: Overlap between the LAM and EAS, red line: Intersphincteric plane for total ISR, Blue line: plane of mistaken dissection during the perineal phase. The anatomic models have been designed according to the descriptions of Muro et al.11 and Tsukada et al. ${ }^{15}$

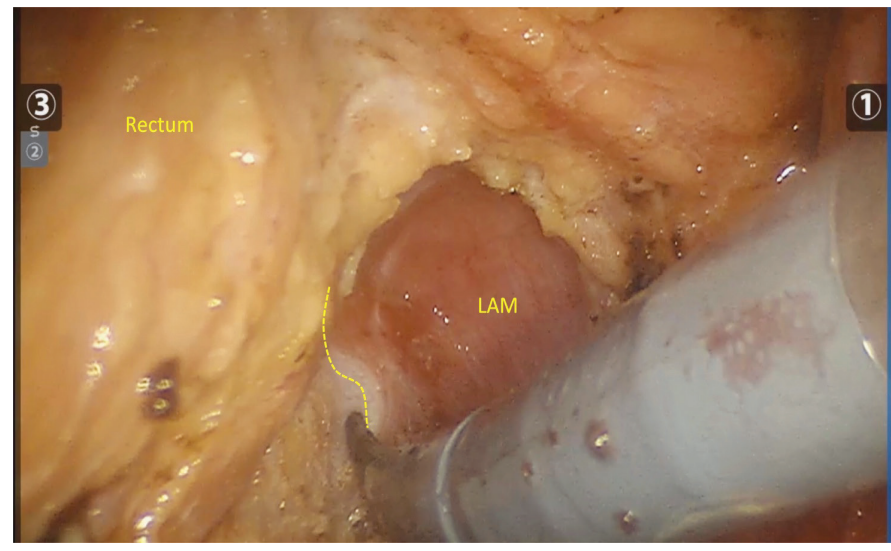

Figure 9. Intra-operative view of the right lateral dissection. LAM: Levator ani muscle; yellow dotted line: dissection line of the ISP ISP: Intersphincteric plane 
safest and easiest starting point for dissection is at the anterolateral portion, due to the absence of the HL, the wide length of the attachment between the LAM and the LM, and the absence of an overlap between the LAM and the EAS. Therefore, after transecting the LAM close to the LM, the access into the virtual plane between the LM and EAS (Figure 8 ) becomes possible. At the posterior portion, the thick HL must be dissected in order to access the ISP underneath, between the LM and the LAM-EAS complex, which are not tightly attached. Dissection in the anterolateral and posterior portion is easier due to the coplanarity between the abdominal and perianal plane.

The anterior portion is the most challenging because of the local proximity of the genitourinary complex, and the lateral portion is often the cause of dissection misleads. During the perianal phase, after dissecting the plane between the IAS/ LM complex and the EAS, the surgical plane may mistakenly move dorsally to the LAM into the ischiorectal fossa, resulting in a mismatch with the abdominal plane (Figure 8).

\section{Definition of Intersphincteric Resection}

Schiessel et al. ${ }^{2}$ introduced ISR followed by hand-sewn coloanal anastomosis (CAA) in 1994 as an anal-sparing technique for low rectal cancer. ISR is composed of two distinct phases (abdominal and perianal) consisting of TME and excision of the internal anal sphincter. It was originally classified into two types (subtotal and total ISR). ${ }^{2}$ Studies conducted in Japan have further classified ISR into three types according to the extension of the resection: 1) Total ISR, when there is complete removal of the IAS at the intersphincteric groove (ISG); 2) Subtotal ISR, when the resection line lays between the dentate line (DL) and the ISG and 3) Partial ISR, when the resection is at the level of the DL. ${ }^{22,23}$ ISR should be differentiated from Parks' conventional CAA and stapled $\mathrm{CAA}^{24}$ and also from ultra-low anterior resection with CAA, described as transabdominal ISR by some authors ${ }^{25,26}$, in order to be fully compliant with the description of Schiessel et al. ${ }^{2}$.

\section{Indications for Intersphincteric Resection}

ISR is a surgical technique for treating patients with low rectal cancers; however, there is no set definition of such cancers, even if they are generally identified as tumors with a lower margin below 4 or $5 \mathrm{~cm}$ from the $\mathrm{AV}$, or below the pelvic floor muscle. Denost et al. ${ }^{27}$ have recently classified low rectal cancers into four categories to assist decision making between sphincter-saving surgery versus APR, and which type of sphincter-saving procedure to perform. This classification evaluates the tumor position, from MRI images, only in relation to the LAM and EAS in a frontal view, without considering the circumferential position of the cancer on the anal clock. Kang et al. ${ }^{28}$, through a retrospective analysis of surgical specimens, have analyzed the circumferential tumor location, reporting that the anterior aspect most frequently involves the CRM and exhibits deeper tumor invasion. Further studies are needed in order to determine whether the circumferential tumor location may play a role in future treatment strategies, such as a stronger indication for preoperative radiation or the choice of a surgical approach.

In 2012, Martin et al. ${ }^{29}$ identified the following indication criteria for ISR: rectal tumors with no evidence of extension into the EAS and/or LAM; distal margin of at least $2 \mathrm{~cm}$ for T2/T3 tumors or $1 \mathrm{~cm}$ for T1 tumors; exclusion of poorly differentiated adenocarcinoma diagnosed by biopsy and/or preoperative documented impaired fecal continence. These indication criteria were recently confirmed by a national based questionnaire evaluation conducted by the Japanese Society for Cancer of the Colon and Rectum. ${ }^{30}$

In our center, ISR is indicated in the following two circumstances: 1) As an alternative to APR for very low lying rectal cancers (below $4 \mathrm{~cm}$ from the $\mathrm{AV}$, with preoperative radiation in the case of cT3);2) As a conversion from an ultra-low anterior resection in the case of involvement/ threatening of the distal gross margin in the resected specimen or in the case of stapler failure for any reason. A hand-sewn side-to-end CAA is performed in most cases of ISR after transanal specimen retrieval. Specimen extraction is carried out through the abdominal wall if the tumor is large or the mesentery is thick, making trans-anal delivery difficult. In such cases, after abdominal extracorporeal resection of the specimen, the returned proximal colon is brought down through the anus, and the CAA is performed in the usual manner.

\section{Standard Features for High-quality Rectal Resections}

The primary aim in rectal cancer surgery is to achieve a goodquality TME as described by Heald ${ }^{31}$, achieving clearance of two margins: distal and circumferential. The adequacy of the distal rectal resection margin (DRM) has decreased from the historically required $5 \mathrm{~cm}$ down to $2 \mathrm{~cm} .{ }^{32,33,34}$ Since 2005, a DRM of $1 \mathrm{~cm}$ has been acceptable for most tumors ${ }^{35,36}$, down to a further $5 \mathrm{~mm}$ acceptable margin being suggested by some authors for those receiving neoadjuvant treatment. ${ }^{37}$ However, because of the difficult intraoperative identification of the DRM after neoadjuvant treatment, many surgeons aim to achieve a minimum of $1 \mathrm{~cm} .{ }^{27}$ Moreover, the authors have recently found no correlation between oncological outcomes (local recurrence, overall survival and disease-free survival) and DRM $<1 \mathrm{~cm}$, with no significant difference also in a subgroup analysis between the DRM $\leq 0.5 \mathrm{~cm}$ group and the $0.5<\mathrm{DRM} \leq 1 \mathrm{~cm}$ group. ${ }^{38}$ 
Rullier et al. ${ }^{39}$ suggested that partial or total removal of the IAS may permit a safe DRM in all cases. However, for low rectal cancers the concept of DRM should be replaced with the principle of the circumferential resection margin (CRM) in order to achieve an oncologically safe resection. A positive CRM, under $1 \mathrm{~mm}$, is associated with a higher rate of local recurrence following rectal resection, regardless of neoadjuvant treatment. ${ }^{40,41}$ In low rectal cancers, a positive CRM may cause tumor infiltration into the skeletal muscles of the pelvic floor (EAS and LAM). This makes the preoperative evaluation imperative during cancer staging with a pelvic MRI, and if available, anorectal $\mathrm{EUS}^{42,43,44}$, in order to better define the surgical strategy (anal-sparing vs APR).

\section{Robotics for Optimal Intersphincteric Resection}

The role of laparoscopy in colorectal cancer surgery has undergone several randomized trials that reported it to be oncologically safe, with no difference in overall survival (OS) or disease-free survival (DFS), with improved short term outcomes (improved postoperative pain, reduced blood loss, reduced ileus rate and cosmesis leading to an earlier recovery and hospital discharge) but with a longer learning curve compared with open surgery. ${ }^{4,45,46,47,48,49}$ However, the CLASSIC trial documented higher CRM-positive rates in the laparoscopic group compared with the open group (12.4\% vs $6.3 \%) .{ }^{4}$ Several technical aspects may have partially affected oncological outcomes, such as the use of rigid, straight, unarticulated instruments in the narrow pelvis, an assistant-dependent, unstable 2-dimensional unmagnified view and poor ergonomics. ${ }^{4,5}$ A steep and long learning curve, together with the above technical limitations, has increased interest in the robotic platform for pelvic surgery. Robotic surgery with the introduction of the da Vinci Surgical System (Intuitive Surgical, Sunnyvale, CA, USA) has revolutionized the way complex surgery is performed by eliminating physiologic tremors and providing better ergonomics, an extra working arm, improved dexterity (articulated instruments with seven degrees of freedom), motion scaling, a magnified 3-dimensional stereoscopic view and a surgeon-controlled stable camera. ${ }^{5}$ The robotic platform enables the surgeon to perform a stable and fine dissection in the narrow and deep pelvic cavity. ${ }^{50,51,52,53}$ The lack of haptic feedback can potentially increase the risk of tissue damage during dissection and traction, but this technical issue can be overcome by using visual signs coupled with experience. ${ }^{54}$

Despite the increasing penetration of robotics in colorectal surgery, there is a lack of high-quality evidence-based studies reporting its superiority over conventional laparoscopic surgery. The current published literature is still based on individual institutions, case series, retrospective studies and meta-analyses with a few underpowered trials. ${ }^{55}$

Intersphincteric dissection (ISD) is one of the most technically demanding rectal surgical procedures. The technical advantages provided by the robotic platform, including clear visibility and wristed instruments, are key to reducing injuries to the adjacent structures during pelvic dissection. Moreover, the robotic approach helps further the depth of the abdominal phase of the ISD, which in turn decreases the duration of the more challenging perineal procedure.

\section{Oncological Outcomes with Robotic ISD}

Studies comparing open and laparoscopic ISR have reported long-term survival data with 5-year OS, DFS and LR rates ranging from $62 \%$ to $97 \%, 66.7 \%$ to $87 \%$ and 0 to $23 \%$, respectively. ${ }^{56,57,58,59,60,61,62,63,64}$

A recent review by Shirouzu et al. ${ }^{3}$ on a total of 22 studies evaluated oncological outcomes after ISR for both open and laparoscopic approaches. The results showed a radical resection (R0 resection) in over $90 \%$ of patients, but there was wide variation in the reported resection margins: the DRM was between 5 and $25 \mathrm{~mm}$, and the CRM was $\leq 1 \mathrm{~mm}$ in $4 \%$ to $19.6 \%$ of cases. There was also wide variation in the reported survival rates, with disease-free and overall 5-year survival rates ranging from $68 \%$ to $86 \%$ and $76 \%$ to $97 \%$, respectively.

The main concern for ISR is local recurrence in the pelvic cavity (including at the anastomotic site), which is reported to be between 0 and $22.7 \%{ }^{3}$ Neoadjuvant CRT is used to both down-size the tumor and down-stage the disease and is a standard strategy to avoid positive CRM and reduce LR in locally advanced rectal cancer as per the NCCN guidelines. ${ }^{65,66,67}$ However, in Japan, neoadjuvant CRT is not carried out for resectable cTl-3 tumors, regardless of the presence of lymph node metastasis within the $\mathrm{TME}^{3}$, with Akagi et al. ${ }^{68}$ reporting a low rate of LR (4.8\%). In Japan and South Korea, there are several concerns regarding the role of neoadjuvant RT in patients undergoing ISR, such as associated higher surgical complications ${ }^{65}$, a negative impact on anal function ${ }^{69,70}$ and sexual disorders ${ }^{71}$, with no clear survival benefit. ${ }^{66}$

In the author's center, neoadjuvant RT is offered if the staging pelvic MRI shows a threatened or suspicious CRM and/or in the presence of lymph nodes $>5 \mathrm{~mm}$ in the shortaxis diameter on the lateral pelvis outside the TME plane. The recorded local recurrence rate of $5.6 \%$ after 2 years is in range with published literature. ${ }^{72,73,74}$

Publications on robotic ISR with significant patient numbers or follow-up periods is lacking in the literature. Kim et al. ${ }^{75}$ published a long-term retrospective study on robotic ISR 
patients, reporting 5-year cumulative rates of LR, OS and DFS of $2.5 \%, 86.7 \%$ and $80.7 \%$, respectively.

A multicenter study involving seven institutions from the Korean Laparoscopic Colorectal Surgery Study Group aimed to verify the long-term safety of robotic ISR for low rectal cancer compared with laparoscopic ISR by analyzing long-term follow-up outcomes with a relatively large patient population. ${ }^{6}$ There was no statistically significant difference reported between cT3-4 tumors in the robotic and laparoscopic groups in either 3-year LR (9\%, p=0.930) or 3-year DFS (76\%, $\mathrm{p}=0.887){ }^{6}$

The authors have published a retrospective study on 70 patients with a median follow-up of 36.5 months (range 3.769.9) for the laparoscopic group and 33.9 months (range 4.4-61.3) for the robotic group and showed no significant differences in 3-year OS (88.5 vs. 95.2\%; $\mathrm{p}=0.174$ ), 3-year RFS (75.0 vs. $76.7 \%$; $\mathrm{p}=0.946)$ and 3-year local RFS (91.7 vs. $87.2 \%$; $\mathrm{p}=0.466) .{ }^{76}$ The 3 - year follow-up data can be regarded as clinically significant, as nearly $80 \%$ of rectal cancer recurrences occur within 2 years of surgery. ${ }^{77}$

\section{Functional Outcomes with Robotic ISD}

After a safe oncological clearance, functional outcomes must also be an important consideration for colorectal surgeons. The anatomical complexity of the pelvis makes surgical dissection very challenging with potential injury to the genitourinary and ano-rectal organs. A thorough knowledge of its anatomy, including the autonomic nerves of the pelvis, may help decrease the functional impact of surgery in the patient. In a dissection study on cadavers, Acar et al. ${ }^{78}$ described that the autonomic nerves can be damaged in four crucial areas during Total mesorectal excision (TME): around the origin of the inferior mesenteric artery; in front of the promontory; at the side walls of the pelvis and at the posterolateral corners of the prostate.

Rectal resections have been associated with impairment of urinaryand sexual function, with reports oflaparoscopic rectal resections fairing worse than their open counterparts ${ }^{79,80,81}$, whilst there are studies reporting the robotic platform showing an advantage over laparoscopic rectal surgery. ${ }^{82,83,84}$ Kim et al. ${ }^{82}$ reported earlier functional recovery in the robotic group compared with the laparoscopic group, while D'Annibale et al. ${ }^{84}$ reported complete restoration of erectile function only in the robotic group. The improvement of sexual and urinary functions after robotic surgery may be associated with better nerve visualization and preservation due to the 3-dimensional magnified camera view and the more precise dissection possible in the robotic platform. ${ }^{5}$ Urinary and male sexual dysfunction is not worsened by the ISR technique itself but related to the general TME. ${ }^{6,75,85}$
ISR, like traditional APR, aims to provide an oncologically safe resection for very low rectal cancers, but unlike APR, employs an anal-sparing technique, which can have an impact on the patient's quality of life..$^{50}$ Two studies reported that robotic ISR was associated with fewer fecal incontinence rates and better sexual function recovery when compared with open surgery. 6,7

A comprehensive paper by Kim et al. ${ }^{75}$ comparing robotic low anterior resection with or without ISR showed significantly higher fecal incontinence scores in total ISR than in partial/subtotal ISR $(\mathrm{p}<0.001-0.05)$ in the first 1224 months after surgery. However, when compared with low anterior resections, any extent of ISR is associated with worse fecal incontinence scores in all forms (solid, liquid, gas incontinence and wearing a pad) ( $\mathrm{p} \leq 0.001-0.005)$. It also reported that compared to pre-op manometric measurements (mean resting pressure, maximal squeezing pressure, urge to defecate volume and maximal tolerance volume), this was reduced 24 months postoperatively in the ISR group, with a recovery to an acceptable continence level in the latter period, as observed in other studies. ${ }^{63,75,86,87}$ Age, female gender, advanced tumor stage, lower tumor location, neoadjuvant CRT, manual anastomosis, and longer operative time were factors significantly associated to worse manometry values. ${ }^{58,75}$

In our institute, we evaluated functional outcomes through Wexner scores ${ }^{88}$ and a functional questionnaire developed by our colorectal division evaluating stool frequency per day, fecal urgency, and day/night-time leakage in patients who had undergone laparoscopic or robotic ISR with at least 12 months follow-up after ileostomy closure. ${ }^{76}$ There was no difference in continence between the laparoscopic and robotic groups, with neoadjuvant CRT being the only factor to affect the Wexner score in a multivariate analysis, confirming the negative role of adjuvant radiation therapy on anorectal function. ${ }^{89,90}$ However, the number of responses was only 30 of 70 questionnaires, with a potential for a non-response bias in the results. In the authors' clinical experience, partial or subtotal ISR are believed to have a better functional outcome than total ISR, which is often hardly considered in comparison with APR during surgical planning, but the data are still under revision for an official report.

The technical advantages of the robotic platform can open up the possibility of an exclusively trans-abdominal approach to the dissection of the LAM and EAS, which in turn can reduce muscular injuries to the sphincter complex and affect function. . $^{726,50,91}$

Finally, surgeons who perform ISR should be aware of the potential risk of postoperative painful edematous hemorrhoids, as described by one case report but anecdotally 
encountered by many surgeons ${ }^{92}$, as a possible indication for prophylactic hemorrhoidectomy during coloanal anastomosis in patients with known external hemorrhoids. Additional studies are needed to describe the impact of symptomatic post-operative hemorrhoidal disease and the role of a preventive treatment.

Functional outcomes should be studied further in order to better understand the impact on quality of life of ISR as a sphincter-saving resection technique, as it has been demonstrated to have a significant impact not only on working and social life but, interestingly, also on a more intimately spiritual aspect in a religious community ${ }^{93}$; however, stoma support with pre- and postoperative health and religious counselling could reduce this impact. ${ }^{94}$

Further multicentric studies are required to better characterize postoperative functions and symptoms, such as those of low anterior resection syndrome in patients undergoing to robotic ISR.

\section{Conclusion}

ISR is a challenging surgical technique that requires a thorough knowledge of the deep pelvic space.

ISR requires careful patient selection, adding functional evaluation to the oncological staging, as this will affect the individual surgical strategy.

Robotic ISR enables a nearly total abdominal approach for low lying rectal cancers and reduces the percentage of APR by providing a sphincter-saving procedure with satisfactory functional and good oncological outcomes. Further multicenter randomized studies are needed to confirm the positive results regarding robotic ISR, as the majority of published studies are from single surgeon's experiences in highly trained settings.

Peer-review: Internally peer reviewed.

\section{Authorship Contributions}

Surgical and Medical Practices: S.H.K., Concept: G.N.P., S.H.K., Design: G.N.P., H.P., S.H.K., Analysis or Interpretation: H.P., S.H.K., Literature Search: G.N.P., T.S.C., Writing: G.N.P., H.P.

Conflict of Interest: No conflict of interest was declared by the authors.

Financial Disclosure: The authors declared that this study received no financial support.

\section{References}

1. Miles WE. A method of performing abdomino-perineal excision for carcinoma of the rectum and of the terminal portion of the pelvic colon. Lancet 1908;2:1812-1813.

2. Schiessel R, Karner-Hanusch J, Herbst F, Teleky B, Wunderlich M Intersphincteric resection for low rectal tumours. Br J Surg 1994;81:13761378 .
3. Shirouzu K, Murakami N, Akagi Y. Intersphincteric resection for very low rectal cancer: A review of the updated literature. Ann Gastroenterol Surg $2017 ; 1: 24-32$

4. Guillou PJ, Quirke P, Thorpe H, Walker J, Jayne DG, Smith AM, et al. Short-term endpoints of conventional versus laparoscopic-assisted surgery in patients with colorectal cancer (MRC CLASICC trial): multicentre, randomised controlled trial. Lancet 2005;365:1718-1726.

5. Chouhan H, Shin J, Kim SH. Is robotic rectal resection the preferred option for resectable cancer? Mini-invasive Surg 2018;2:18.

6. Park JS, Kim NK, Kim SH, Lee KY, Lee KY, Shin JY, et al. Multicentre study of robotic intersphincteric resection for low rectal cancer. Br J Surg 2015; 102:1567-1573.

7. Kim JC, Lim SB, Yoon YS, Park IJ, Kim CW, Kim CN. Completely abdominal intersphincteric resection for lower rectal cancer: feasibility and comparison of robot-assisted and open surgery. Surg Endosc 2014;28:2734-2744.

8. Acar HA, Kuzu MA. Anatomical Planes in Rectal Cancer Surgery. Turk J Colorectal Dis 2019;29:165-170.

9. Muro S, Kagawa R, Habu M, Ka H, Harada M, Akita K. Coexistence of Dense and Sparse Areas in the Longitudinal Smooth Muscle of the Anal Canal: Anatomical and Histological Analyses Inspired by Magnetic Resonance Images. Clin Anat 2019

10. Parks AG. A note on the anatomy of the anal canal. Proc R Soc Med 1954:47:997-998.

11. Muro S, Yamaguchi K, Nakajima Y, Watanabe K, Harada M, Nimura A, et al. Dynamic intersection of the longitudinal muscle and external anal sphincter in the layered structure of the anal canal posterior wall. Surg Radiol Anat 2014:36:551-559.

12. Toldt B. Anatomischer atlas fur studierende und arzte. 4. Berlin, pp $1903 ; 526-538$

13. Milligan E, Morgan C. Surgical anatomy of the anal canal with special reference to anorectal fistule. Lancet 1934;lancet 2:1150-1156.

14. Goligher J. Surgery of the anus, rectum and colon, 4th Edn. London. 1980.

15. Tsukada Y, Ito M, Watanabe K, Yamaguchi K, Kojima M, Hayashi R, et al. Topographic Anatomy of the Anal Sphincter Complex and Levator Ani Muscle as It Relates to Intersphincteric Resection for Very Low Rectal Disease. Dis Colon Rectum 2016;59:426-433.

16. Shafik A. New concept of the anatomy of the anal sphincter mechanism and the physiology of defecation. II. Anatomy of the levator ani muscle with special reference to puborectalis. Invest Urol 1975;13:175-182.

17. Nakajima Y, Muro S, Nasu H, Harada M, Yamaguchi K, Akita K. Morphology of the region anterior to the anal canal in males: visualization of the anterior bundle of the longitudinal muscle by transanal ultrasonography. Surg Radiol Anat 2017;39:967-973.

18. Muro S, Tsukada Y, Harada M, Ito M, Akita K. Anatomy of the smooth muscle structure in the female anorectal anterior wall: convergence and anterior extension of the internal anal sphincter and longitudinal muscle. Colorectal Dis 2019;21:472-480.

19. Gray H, Standring S, Anand N. Gray's Anatomy: The Anatomical Basis of Clinical Practice, 4lst edn. Philadelphia, PA: Elsevier,. 2016.

20. Muro S, Tsukada Y, Harada M, Ito M, Akita K. Spatial distribution of smooth muscle tissue in the male pelvic floor with special reference to the lateral extent of the rectourethralis muscle: Application to prostatectomy and proctectomy. Clin Anat 2018;31:1167-1176.

21. Oh C, Kark AE. Anatomy of the perineal body. Dis Colon Rectum $1973 ; 16: 444-454$

22. Akagi Y, Kinugasa T, Shirouzu K. Intersphincteric resection for very low rectal cancer: a systematic review. Surg Today 2013;43:838-847.

23. Saito N, Moriya Y, Shirouzu K, Maeda K, Mochizuki H, Koda K, et al Intersphincteric resection in patients with very low rectal cancer: a review of the Japanese experience. Dis Colon Rectum 2006;49(10 Suppl):S13-S22. 
24. Parks AG. Transanal technique in low rectal anastomosis. Proc R Soc Med 1972;65:975-976.

25. Kim JC, Lee JL, Alotaibi AM, Yoon YS, Kim CW, Park IJ. Robot-assisted intersphincteric resection facilitates an efficient sphincter-saving in patients with low rectal cancer. Int J Colorectal Dis 2017;32:1137-1145.

26. Park SY, Choi GS, Park JS, Kim HJ, Choi WH, Ryuk JP. Robotic-assisted transabdominal intersphincteric resection: a technique involving a completely abdominal approach and coloanal anastomosis. Surg Laparosc Endosc Percutan Tech 2013;23:e5-el0.

27. Denost Q, Rullier E. Intersphincteric Resection Pushing the Envelope for Sphincter Preservation. Clin Colon Rectal Surg 2017;30:368-376.

28. Kang BM, Park YK, Park SJ, Lee KY, Kim CW, Lee SH. Does circumferential tumor location affect the circumferential resection margin status in mid and low rectal cancer? Asian J Surg 2018;41:257-263.

29. Martin ST, Heneghan HM, Winter DC. Systematic review of outcomes after intersphincteric resection for low rectal cancer. Br J Surg 2012;99:603-612.

30. Yamada K, Saiki Y, Takano S, Iwamoto K, Tanaka M, Fukunaga M, et al. Long-term results of intersphincteric resection for low rectal cancer in Japan. Surg Today 2019;49:275-285.

31. Heald RJ, Moran BJ, Ryall RD, Sexton R, MacFarlane JK. Rectal cancer: the Basingstoke experience of total mesorectal excision, 1978-1997. Arch Surg 1998;133:894-899.

32. Goligher JC, Dukes CE, Bussey HJR. Local recurrences after sphincter saving excisions for carcinoma of the rectum and rectosigmoid. Br J Surg 1951;39:199-211.

33. Pollett WG, Nicholls RJ. The relationship between the extent of distal clearance and survival and local recurrence rates after curative anterior resection for carcinoma of the rectum. Ann Surg 1983;198:159-163.

34. Williams NS, Dixon MF, Johnston D. Reappraisal of the 5 centimetre rule of distal excision for carcinoma of the rectum: a study of distal intramural spread and of patients' survival. Br J Surg 1983;70:150-154.

35. Shirouzu K, Isomoto H, Morodomi T, Kakegawa T. Carcinomatous lymphatic permeation. Prognostic significance in patients with rectal carcinoma--a long term prospective study. Cancer 1995;75:4-10.

36. Ueno H, Mochizuki H, Hashiguchi Y, Ishikawa K, Fujimoto H, Shinto E, Hase K. Preoperative parameters expanding the indication of sphincter preserving surgery in patients with advanced low rectal cancer. Ann Surg 2004;239:34-42.

37. Pahlman L, Bujko K, Rutkowski A, Michalski W. Altering the therapeutic paradigm towards a distal bowel margin of $<1 \mathrm{~cm}$ in patients with lowlying rectal cancer: a systematic review and commentary. Colorectal Dis 2013;15:e166-174.

38. Kang DW, Kwak HD, Sung NS, Yang IS, Baek SJ, Kwak JM, et al. Oncologic outcomes in rectal cancer patients with a $</=1$-cm distal resection margin. Int J Colorectal Dis 2017;32:325-332.

39. Rullier E, Laurent C, Bretagnol F, Rullier A, Vendrely V, Zerbib F. Sphincter-saving resection for all rectal carcinomas: the end of the 2-cm distal rule. Ann Surg 2005;241:465-469.

40. Quirke P, Durdey P, Dixon MF, Williams NS. Local recurrence of rectal adenocarcinoma due to inadequate surgical resection. Histopathological study of lateral tumour spread and surgical excision. Lancet 1986;2:996999.

41. Birbeck KF, Macklin CP, Tiffin NJ, Parsons W, Dixon MF, Mapstone NP, Abbott CR, Scott N, Finan PJ, Johnston D, Quirke P. Rates of circumferential resection margin involvement vary between surgeons and predict outcomes in rectal cancer surgery. Ann Surg 2002;235:449-457.

42. Taylor FG, Quirke P, Heald RJ, Moran B, Blomqvist L, Swift I, et al. One millimetre is the safe cut-off for magnetic resonance imaging prediction of surgical margin status in rectal cancer. Br J Surg 2011;98:872-879.

43. Taylor FG, Quirke P, Heald RJ, Moran B, Blomqvist L, Swift I, et al. Preoperative high-resolution magnetic resonance imaging can identify good prognosis stage I, II, and III rectal cancer best managed by surgery alone: a prospective, multicenter, European study. Ann Surg 2011;253:711-719.

44. Taylor FG, Quirke P, Heald RJ, Moran BJ, Blomqvist L, Swift IR, SebagMontefiore D, Tekkis P, Brown G, Magnetic Resonance Imaging in Rectal Cancer European Equivalence Study Study G. Preoperative magnetic resonance imaging assessment of circumferential resection margin predicts disease-free survival and local recurrence: 5-year follow-up results of the MERCURY study. J Clin Oncol 2014;32:34-43.

45. Kang SB, Park JW, Jeong SY, Nam BH, Choi HS, Kim DW, et al. Open versus laparoscopic surgery for mid or low rectal cancer after neoadjuvant chemoradiotherapy (COREAN trial): short-term outcomes of an open-label randomised controlled trial. Lancet Oncol 2010;11:637-645.

46. Leung KL, Kwok SP, Lam SC, Lee JF, Yiu RY, Ng SS, et al. Laparoscopic resection of rectosigmoid carcinoma: prospective randomised trial. Lancet 2004;363:1187-1192.

47. Milsom JW, Bohm B, Hammerhofer KA, Fazio V, Steiger E, Elson P. A prospective, randomized trial comparing laparoscopic versus conventional techniques in colorectal cancer surgery: a preliminary report. J Am Coll Surg 1998;187:46-54; discussion 54-45.

48. van der Pas MH, Haglind E, Cuesta MA, Furst A, Lacy AM, Hop WC, et al. Laparoscopic versus open surgery for rectal cancer (COLOR II): short-term outcomes of a randomised, phase 3 trial. Lancet Oncol 2013;14:210-218.

49. Kim NK, Kim MS, Al-Asari SF. Update and debate issues in surgical treatment of middle and low rectal cancer. J Korean Soc Coloproctol 2012;28:230-240.

50. Park SY, Choi GS, Park JS, Kim HJ, Ryuk JP. Short-term clinical outcome of robot-assisted intersphincteric resection for low rectal cancer: a retrospective comparison with conventional laparoscopy. Surg Endosc 2013;27:48-55.

51. Leong QM, Son DN, Cho JS, Baek SJ, Kwak JM, Amar AH, et al. Robotassisted intersphincteric resection for low rectal cancer: technique and short-term outcome for 29 consecutive patients. Surg Endosc 2011;25:2987-2992.

52. Hellan M, Stein H, Pigazzi A. Totally robotic low anterior resection with total mesorectal excision and splenic flexure mobilization. Surg Endosc 2009;23:447-451.

53. Kim SH, Kwak JM. Robotic total mesorectal excision: operative technique and review of the literature. Tech Coloproctol 2013;17 Suppl 1:S47-53.

54. Baik SH. Robotic colorectal surgery. Yonsei Med J 2008;49:891-896.

55. Ngu JC, Kim SH. Robotic surgery in colorectal cancer: the way forward or a passing fad. J Gastrointest Oncol 2019;10:1222-1228.

56. Braun J, Treutner KH, Winkeltau G, Heidenreich U, Lerch MM, Schumpelick V. Results of intersphincteric resection of the rectum with direct coloanal anastomosis for rectal carcinoma. Am J Surg 1992;163:407412 .

57. Schiessel R, Novi G, Holzer B, Rosen HR, Renner K, Holbling N, et al. Technique and long-term results of intersphincteric resection for low rectal cancer. Dis Colon Rectum 2005;48:1858-1865; discussion 1865-1857.

58. Chamlou R, Parc Y, Simon T, Bennis M, Dehni N, Parc R, et al. Longterm results of intersphincteric resection for low rectal cancer. Ann Surg 2007;246:916-921; discussion 921-912.

59. Han JG, Wei GH, Gao ZG, Zheng Y, Wang ZJ. Intersphincteric resection with direct coloanal anastomosis for ultralow rectal cancer: the experience of People's Republic of China. Dis Colon Rectum 2009;52:950-957.

60. Weiser MR, Quah HM, Shia J, Guillem JG, Paty PB, Temple LK, et al. Sphincter preservation in low rectal cancer is facilitated by preoperative chemoradiation and intersphincteric dissection. Ann Surg 2009;249:236242.

61. Park JS, Choi GS, Jun SH, Hasegawa S, Sakai Y. Laparoscopic versus open intersphincteric resection and coloanal anastomosis for low rectal cancer: intermediate-term oncologic outcomes. Ann Surg 2011;254:941-946. 
62. Laurent C, Paumet T, Leblanc F, Denost Q, Rullier E. Intersphincteric resection for low rectal cancer: laparoscopic vs open surgery approach. Colorectal Dis 2012;14:35-41; discussion 42-33.

63. Saito N, Ito M, Kobayashi A, Nishizawa Y, Kojima M, Nishizawa Y, et al. Long-term outcomes after intersphincteric resection for low-lying rectal cancer. Ann Surg Oncol 2014;21:3608-3615.

64. Koyama M, Murata A, Sakamoto Y, Morohashi H, Takahashi S, Yoshida E, et al. Long-term clinical and functional results of intersphincteric resection for lower rectal cancer. Ann Surg Oncol 2014;21 Suppl 3:S422-428.

65. Kapiteijn E, Marijnen CA, Nagtegaal ID, Putter H, Steup WH, Wiggers T, et al. Preoperative radiotherapy combined with total mesorectal excision for resectable rectal cancer. N Engl J Med 2001;345:638-646.

66. Peeters KC, Marijnen CA, Nagtegaal ID, Kranenbarg EK, Putter H, Wiggers $\mathrm{T}$, et al. The TME trial after a median follow-up of 6 years: increased local control but no survival benefit in irradiated patients with resectable rectal carcinoma. Ann Surg 2007;246:693-701.

67. Rectal Cancer (Version 1.2020). https://www.nccn.org/professionals/ physician_gls/PDF/rectal.pdf [February 24, 2020.

68. Akagi Y, Shirouzu K, Ogata Y, Kinugasa T. Oncologic outcomes of intersphincteric resection without preoperative chemoradiotherapy for very low rectal cancer. Surg Oncol 2013;22:144-149.

69. Ito M, Saito N, Sugito M, Kobayashi A, Nishizawa Y, Tsunoda Y. Analysis of clinical factors associated with anal function after intersphincteric resection for very low rectal cancer. Dis Colon Rectum 2009;52:64-70.

70. Hassan I, Larson DW, Wolff BG, Cima RR, Chua HK, Hahnloser D, O'Byrne MM, Larson DR, Pemberton JH. Impact of pelvic radiotherapy on morbidity and durability of sphincter preservation after coloanal anastomosis for rectal cancers. Dis Colon Rectum 2008;51:32-37.

71. Bonnel C, Parc YR, Pocard M, Dehni N, Caplin S, Parc R, Tiret E. Effects of preoperative radiotherapy for primary resectable rectal adenocarcinoma on male sexual and urinary function. Dis Colon Rectum 2002;45:934-939.

72. Kim SH, Park IJ, Joh YG, Hahn KY. Laparoscopic resection of rectal cancer: a comparison of surgical and oncologic outcomes between extraperitoneal and intraperitoneal disease locations. Dis Colon Rectum 2008;51:844-851.

73. Baek SJ, Kim SH, Kwak JM, Cho JS, Shin JW, Amar AH, Kim J. Selective use of preoperative chemoradiotherapy for $\mathrm{T} 3$ rectal cancer can be justified: analysis of local recurrence. World J Surg 2013;37:220-226.

74. Feeney G, Sehgal R, Sheehan M, Hogan A, Regan M, Joyce M, Kerin M. Neoadjuvant radiotherapy for rectal cancer management. World J Gastroenterol 2019;25:4850-4869.

75. Kim JC, Lee JL, Bong JW, Seo JH, Kim CW, Park SH, et al. Oncological and anorectal functional outcomes of robot-assisted intersphincteric resection in lower rectal cancer, particularly the extent of sphincter resection and sphincter saving. Surg Endosc 2019.

76. Yoo BE, Cho JS, Shin JW, Lee DW, Kwak JM, Kim J, et al. Robotic versus laparoscopic intersphincteric resection for low rectal cancer: comparison of the operative, oncological, and functional outcomes. Ann Surg Oncol 2015;22:1219-1225.

77. Waldron RP, Donovan IA. Clinical follow-up and treatment of locally recurrent colorectal cancer. Dis Colon Rectum 1987;30:428-430.

78. Acar HI, Kuzu MA. Important points for protection of the autonomic nerves during total mesorectal excision. Dis Colon Rectum 2012;55:907-912.
79. Jayne DG, Brown JM, Thorpe H, Walker J, Quirke P, Guillou PJ. Bladder and sexual function following resection for rectal cancer in a randomized clinical trial of laparoscopic versus open technique. Br J Surg 2005;92:11241132.

80. Sartori CA, Sartori A, Vigna S, Occhipinti R, Baiocchi GL. Urinary and sexual disorders after laparoscopic TME for rectal cancer in males. J Gastrointest Surg 2011;15:637-643.

81. Morino M, Parini U, Allaix ME, Monasterolo G, Brachet Contul R, Garrone C. Male sexual and urinary function after laparoscopic total mesorectal excision. Surg Endosc 2009;23:1233-1240

82. Kim JY, Kim NK, Lee KY, Hur H, Min BS, Kim JH. A comparative study of voiding and sexual function after total mesorectal excision with autonomic nerve preservation for rectal cancer: laparoscopic versus robotic surgery. Ann Surg Oncol 2012;19:2485-2493.

83. Luca F, Valvo M, Ghezzi TL, Zuccaro M, Cenciarelli S, Trovato C, et al. Impact of robotic surgery on sexual and urinary functions after fully robotic nerve-sparing total mesorectal excision for rectal cancer. Ann Surg 2013;257:672-678.

84. D'Annibale A, Pernazza G, Monsellato I, Pende V, Lucandri G, Mazzocchi P, Alfano G. Total mesorectal excision: a comparison of oncological and functional outcomes between robotic and laparoscopic surgery for rectal cancer. Surg Endosc 2013;27:1887-1895.

85. Lange MM, van de Velde CJ. Urinary and sexual dysfunction after rectal cancer treatment. Nat Rev Urol 2011;8:51-57.

86. Bordeianou L, Maguire LH, Alavi K, Sudan R, Wise PE, Kaiser AM, Sphincter-sparing surgery in patients with low-lying rectal cancer: techniques, oncologic outcomes, and functional results. J Gastrointest Surg 2014;18:1358-1372.

87. Barisic G, Markovic V, Popovic M, Dimitrijevic I, Gavrilovic P, Krivokapic Z. Function after intersphincteric resection for low rectal cancer and its influence on quality of life. Colorectal Dis 2011;13:638-643.

88. Jorge JM, Wexner SD. Etiology and management of fecal incontinence. Dis Colon Rectum 1993;36:77-97.

89. Ammann K, Kirchmayr W, Klaus A, Muhlmann G, Kafka R, Oberwalder $\mathrm{M}$, et al. Impact of neoadjuvant chemoradiation on anal sphincter function in patients with carcinoma of the midrectum and low rectum. Arch Surg 2003;138:257-261.

90. Pollack J, Holm T, Cedermark B, Holmstrom B, Mellgren A. Long-term effect of preoperative radiation therapy on anorectal function. Dis Colon Rectum 2006;49:345-352.

91. Pigazzi A, Ellenhorn JD, Ballantyne GH, Paz IB. Robotic-assisted laparoscopic low anterior resection with total mesorectal excision for rectal cancer. Surg Endosc 2006;20:1521-1525.

92. Leong QM, Son DN, Baek SJ, Cho JS, Amar A, Kwak JM, et al. Edematous and painful external hemorrhoids following intersphincteric resection for low rectal cancer. J Korean Surg Soc 2011;81 Suppl 1:S39-42.

93. Kuzu MA, Topcu O, Ucar K, Ulukent S, Unal E, Erverdi N, et al. Effect of sphincter-sacrificing surgery for rectal carcinoma on quality of life in Muslim patients. Dis Colon Rectum 2002;45:1359-1366.

94. Celasin H, Karakoyun R, Yilmaz S, Elhan AH, Erkek B, Kuzu MA. Quality of life measures in Islamic rectal carcinoma patients receiving counselling. Colorectal Dis 2011;13:e170-e175. 